\title{
ANALISIS AGROINDUSTRI KEDELAI DI KECAMATAN SEBERIDA KABUPATEN INDRAGIRI HULU PRIVINSI RIAU
}

\author{
Reza Gunanda ${ }^{1)}$ dan Septina Elida ${ }^{2)}$ \\ Fakultas Pertanian Universitas Islam Riau
}

\begin{abstract}
ABSTRAK
Kedelai digunakan sebagai bahan baku pada industri pengolahan seperti industri tahu dan tempe. Penelitian ini bertujuan untuk menganalisis : (1) Biaya produksi, pendapatan, efisiensi, nilai tambah dan tingkat pengembalian Investasi (ROI),dan(2) Sikap kewirausahaan pengusaha agroindustri kedelai. Penelitian menggunakan metode survey, yang dilaksanakan di Kecamatan Seberida, dengan responden diambil secara sensus yaitu 9 pengusaha tahu dan 7 pengusaha tempe.Hasil penelitian menunjukkan usaha agroindustri tahu dan tempe merupakan usaha kecil per seorangan, teknologi semi mekanis, belum memiliki merek dagang dan izin usaha secara resmi. Bahan baku yang digunakan dalam satu kali proses untuk agroindustri tahu adalah kedelai sebanyak $144 \mathrm{~kg}$, dengan bahan penunjang berupa air cuka, solar, kayu bakar, dan plastik.Biaya produksi sebesar Rp 1.002.222, biaya terbesar adalah untuk bahan baku yaitu Rp. 1.002.222 (88,88\%), pendapatan bersih Rp 649.384, Nilai tambah sebesar Rp 1.360, RCR sebesar 1,95, dan ROI sebesar59,24 \%.Sedangkan pada agroindustritempe, penggunaan kedelaisebanyak $157 \mathrm{~kg}$, dengan bahan penunjang berupa ragi, daun pisang, kayu bakar, listrik, plastik, dan solar. Biaya produksi agroindustri tempe sebesarRp 1.089.286, biaya terbesar adalah untuk bahan baku yaitu Rp 1.089.286 (85,06\%), pendapatan bersih565.921, RCR sebesar 1,43, nilai tambah diperoleh sebesar Rp 1.665/kg, dan ROI sebesar43,68\%. Pengusaha tahu mempunyai sikap kewirausahaan yang sangat tinggi, sedangkan pengusaha tempe sikap kewirausaannya tinggi.
\end{abstract}

Kata Kunci:Agroindustri,Nilai Tambah, Kedelai, Pendapatan, Sikap

\section{PENDAHULUAN}

Agroindustri merupakan salah satu alternatif pengembangan ekonomi pedesaan. Agroindustri ini mampu meningkatkan pendapatan para pelaku agribisnis,menyerap tenagakerja, meningkatkan perolehan devisa, dan mendorong munculnya industri yang lain (Soekartawi, 2001). Di Riau produksi kedelai beberapa tahun ini mengalami penurunan, Penurunan ini dikarena menurunnya luas panen. Kabupaten Indragiri Hulu produksi kedelai tahun 2012 sebanyak 77 ton mengalami penurunan sebesar 57,14\% pada tahun 2013 menjadi 33 ton dengan produktivitas 1,12 ton/hektar, (BPS Riau, 2014).

Salah satu industri rumah tangga yang cukup berkembang di Kecamatan Seberida Kabupaten Indragiri Hulu adalah industri pengolahan kedelai.Usaha inisudah ada sejak tahun 1995 hingga sekarang, usaha ini berfungsi sebagai salah

100 Analisis Agroindustri Kedelai Di Kecamatan Seberida Kabupaten Indragiri Hulu Privinsi Riau 
satu diversifikasi usaha yang dapat membuka lapangan kerja dan meningkatkan pendapatan keluarga. Industri ini cukup menjanjikan, karena dapat menambah penghasilankeluarga dan mencukupi kebutuhan, menampung banyak tenaga kerja, sehingga dapat mengurangi tingkat pengangguran. Masyarakat Indragiri Hulu khususnya pengusaha kedelai terus berusaha menjalankan industri dengan harapan usaha ini dapat mencukupi kebutuhan sehari-hari,dan agroindustri kedelai mempunyai potensi untuk dikembangkan.

Keberhasilan suatu usaha tidak hanya ditentukan oleh produksi, tersedianya modal, adanya peluang pasar melainkan juga dipengaruhi oleh potensi yang dimiliki pengusaha tersebut. Dengan kata lain tersedianya modal, tingginya jumlah produksi dan terdapatnya peluang pasar tanpa didukung oleh potensi pengusaha tentu tujuan dari usaha tersebut tidak dapat berjalan dengan baik. Potensi pengusaha ini juga sangat ditentukan oleh sikap kewirausahaan yang dapat mendukung pengembangan usahanya, dimana sikap ini dipengaruhi oleh berbagai hal seperti pendidikan dan latihan yang pernah dilakukan.

Berdasarkan uraian tersebut perlu dilakukan penelitian tentang pengolahan kedelai dilihat dari permodalan, bahan baku, teknologi, manajemen usaha dan permasalahan secara kuantitatif, memberikannilai tambah kedelai, pendapatan pengrajin dan penciptaan lapangan kerja atau kesempatan kerja dan melihat bagaimana sikap kewirusahaan agroindustri kedelai.

Penelitian ini bertujuan untuk menganalisis:usaha agroindustri kedelai meliputi teknologi, biaya produksi, produksi,efisiensi, nilai tambah dan tingkat pengembalian investasi (ROI), dan sikap kewirausahaan

Hasil penelitian ini diharapkan dapat menjadi bahan pertimbangan bagi pengusaha dalam pengambilan keputusan, dan bagi pemerintah daerah, bahan pertimbangan dalam menyusun kebijakan yang lebih baik di masa yang akan datang, terutama dalam Agroindustri kedelai pada industri rumah tangga.

\section{METODE PENELITIAN}

\section{Metode, Tempat dan Waktu Penelitian}

Metode dalam penelitian ini adalah survey, dengan lokasi di Kecamatan Seberida Kabupaten Indragiri Hulu Provinsi Riau. Penelitian ini dilakukan selama enam bulan yang dimulai dari Oktober 2015 sampai dengan Maret 2016. 


\section{Teknik Pengambilan Responden}

Populasi dalam penelitian adalah seluruh pengusaha Agroindustri kedelai.Sampel dalam diambil secara sensus, yaitu semua pengusaha agroindustri kedelai. Di Kabupaten Indragiri Hulu dari sebelas desa yang ada, terdapat delapan desa yang melakukan kegiatan Agroindustri kedelai yaitu: Desa Bukit Meranti, kelesa, Seresam, Petala Bumi, Titian Resak, Pangkalan Kasai, Buluh Rampai dan Bandar Padang. Dari desa tersebut terdapat 16 pengusaha agroindustri kedelai yang terdiri dari 9 pengusaha Tahu dan 7 pengusaha Tempe.

\section{Teknik Pengumpulan Data}

Data yang dikumpulkan pada penelitian ini terdiri daridata primer dan data sekunder. Data primer diperoleh melalui wawancara langsung dengan menggunakan kueisioner atau daftar pertanyaan yang telah dipersiapkan dan pengamatan langsung dilapangan. Sumber data primer meliputi identitas pengusaha pengolahan kedelai menjadi tahu dan tempe. Sedangkan data sekunder diperoleh dari instansi terkait yang meliputi keadaan umum daerah penelitian.

\section{Analisis Data}

Data yang telah diperoleh dari respondenkedelai terlebih dahulu ditabulasikan dan kemudian dianalisis secara diskriptif kualitatif dan kuantitatif, disamping itu juga mengguna rumus-rumus sebagai berikut :

Biaya Produksi

Biaya produksi dihitung dengan menggunakan formula rumus menurut Hernanto, (1996) sebagai berikut:

$$
\mathrm{TC}=\mathrm{TFC}+\mathrm{TVC}
$$

Keterangan:

TC : Biaya Produksi ( $\mathrm{Rp} / \mathrm{Kg} /$ Proses Produksi)

TFC : Biaya Tetap Total (Rp/Kg/Proses Produksi)

TVC : Biaya Variabel Total (Rp/Kg/Proses Produksi)

Pendapatan Kotor

Pendapatan kotor usaha agroindustri kedelaiadalah perkalian antara produksi yang diperoleh dengan harga jual, dihitung dengan menggunakan rumus umum menurut, Soekartawi, (1995) sebagai berikut:

$\mathrm{TR}=\mathrm{Y}$. Py 
Keterangan:

TR : Total Penerimaan (Rp/Proses Produksi)

Y : Jumlah Produksi $(\mathrm{Rp} / \mathrm{Kg})$

Py : Harga Jual $(\mathrm{Rp} / \mathrm{Kg})$

Pendapatan Bersih

Pendapatan bersih usaha agroindustri kedelaiadalah selisih antara penerimaan dan semua biaya. Untuk menghitung pendapatan usaha agroindustri digunakan rumus umum menurut (Soekartawi, 1995), yaitu:

$$
\Pi=\mathrm{TR}-\mathrm{TC}
$$

Keterangan:

$\Pi \quad$ : Pendapatan Bersih Usaha (Rp/Proses Produksi)

TR : Total Penerimaan (Rp/Proses Produksi)

TC : Total Biaya (Rp/Proses Produksi)

Efisiensi Usaha Agroindustri

Efisiensi usaha agroindustri kedelai dilakukan dengan menggunakan rumus Return Cost of Ratio menurut Soekartawi (1991), dengan persamaan:

Keterangan :

$$
\mathrm{RCR}=\frac{\mathrm{TR}}{\mathrm{TC}}
$$

RCR

TR

TC
: Return Cost Of Ratio

: Pendapatan Kotor/Total Revenue(Rp/Proses)

: Total Biaya/Total Cost(Rp/Proses)

Dengan kriteria penilaian:

$\mathrm{RCR}>1$, Berarti agroindustri tahu dan tempe menguntungkan.

$\mathrm{RCR}=1$, Berarti agroindustri tahu dan tempe berada pada titik impas.

RCR <1, Berarti agroindustri tahudan tempe tidak menguntungkan.

Analisis Nilai Tambah

Nilai tambah produk agroindustri kedelaidihitung menggunakan metode Hayami. dapat dilihat pada Tabel 1.

\begin{tabular}{|c|c|}
\hline Variabel & Nilai \\
\hline \multicolumn{2}{|l|}{ I. Output, Input dan Harga } \\
\hline 1. Output (kg) & $(1)$ \\
\hline 2. Input $(\mathrm{kg})$ & $(2)$ \\
\hline 3. Tenaga kerja (HOK) & $(3)$ \\
\hline 4. Faktor Konversi & $(4)=(1) /(2)$ \\
\hline 5. Koefisien Tenaga Kerja(HOK/kg) & $(5)=(3) /(2)$ \\
\hline 6. Harga output (Rp) & $(6)$ \\
\hline 7. Upah Tenaga kerja (Rp/HOK) & (7) \\
\hline \multicolumn{2}{|l|}{ II. Penerimaan dan Keuntungan } \\
\hline 8. Harga bahan baku (Rp/kg) & $(8)$ \\
\hline 9. Sumbangan input lain $(\mathrm{Rp} / \mathrm{Kg})$ & (9) \\
\hline
\end{tabular}

Tabel 1. Perhitungan Nilai Tambah Metode Hayami

103 Analisis Agroindustri Kedelai Di Kecamatan Seberida Kabupaten Indragiri Hulu Privinsi Riau 


\begin{tabular}{|l|l|}
\hline 10. Nilai Output $(\mathrm{Rp} / \mathrm{Kg})$ & $(10)=(4) \times(6)$ \\
\hline 11. a. Nilai Tambah $(\mathrm{Rp} / \mathrm{Kg})$ & $(11 \mathrm{a})=(10)-(9)-(8)$ \\
\hline b. Rasio Nilai Tambah $(\%)$ & $(11 \mathrm{~b})=(11 \mathrm{a} / 10) \times 100 \%$ \\
\hline 12. a Pendapatan tenaga kerja $(\mathrm{Rp} / \mathrm{kg})$ & $(12 \mathrm{a})=(5) \times(7)$ \\
\hline b. Pangsa Tenaga kerja $(\%)$ & $(12 \mathrm{~b})=(12 \mathrm{a} / 11 \mathrm{a}) \times 100 \%$ \\
\hline 13. a. Keuntungan $(\mathrm{Rp})$ & $(13 \mathrm{a})=11 \mathrm{a}-12 \mathrm{a}$ \\
\hline b. Tingkat keuntungan $(\%)$ & $(13 \mathrm{~b})=(13 \mathrm{a} / 11 \mathrm{a}) \times 100 \%$ \\
\hline
\end{tabular}

Sumber: Sudiyono, 2004

Analisis Tingkat Pengembalian Investasi(ROI)

Tingkat pengembalian Investasi(ROI) ditentukan menurut rumus Rawuh, (2013), sebagai berikut :

$$
R O I=\frac{P . Q-\sum r i . X i}{\sum r i . X i} \times 100 \%
$$

dimana:

$$
\begin{array}{ll}
\mathrm{ROI} & =\text { Return On Investment } \\
\mathrm{P} . \mathrm{Q} & =\text { Nilai Produksi (Rp/Proses Produksi) } \\
R i & =\text { Harga Input Ke I (Rp/Proses Produksi) } \\
X i & =\text { Jumlah Input/ Faktor Produksi Ke I (Rp/Proses Produksi) }
\end{array}
$$

Kriteria tingkat efisien digunakan:

ROI > Tingkat suku bunga pinjaman bank yang berlaku, maka usaha layak untuk dilaksanakan

ROI $\leq$ Tingkat suku bunga pinjaman bank yang berlaku, maka usaha tidak layak untuk dilaksanakan.

\section{Sikap Kewirausahaan Pengusaha}

Sikap kewirausahaan pengusaha, diukur dengan menggunakan indikator tertentu yang ditetapkan berdasarkan pertanyaan survai lapangan yang relevan. Indikator sikap kewirausahaan yang digunakan yaitu penuh percaya diri,memiliki inisiatif, memiliki motif berprestasi, memiliki jiwa kepemimpinan, berani mengambil risiko dengan penuh perhitungan,(Suryana, 2011).Kemudian dilakukan proses scoring untuk penentuan jumlah skor pada masing-masing responden. Proses scoring ini dilakukan untuk menghitung tingkat sikap kewirausahaan penrajin agroiindutri kedelai. Sikap kewirausahaan masing-masing responden akan dilihat pada total skor dan penggolongan kriteria yang telah ditentukan. 
Skor maksimum dari pernyataan yang menunjukkan sikap kewirausahaan bernilai 25 dan skor minimum dari pernyataan yang menunjukkan sikap kewirausahaan bernilai 5, yang di dapat dari proses pengkelasan, (Haryono, 1984), sebagai berikut:

Jumlah skor maksimum $\quad: 5 \times 5=25$

Jumlah skor minimum $\quad: 5 \times 1=5$

Keterangan : 5 jumlah variabel

5 jumlah kelas (skor)

Jarak kelas $($ range $)=\frac{\text { Skor } \text { maksimum }- \text { Skor minimum }}{\text { Banyak } \text { kelas }}=\frac{25-5}{5}=4$

Kriterianya adalah sebagai berikut :

1. Sikap kewirausahaan pengusaha sangat rendah dinyatakan dengan skor 5-8,9

2. Sikap kewirausahaan pengusaharendah dinyatakan dengan skor 9-12,9

3. Sikap kewirausahaan pengusaha sedang dinyatakan dengan skor 13-16,9

4. Sikap kewirausahaan pengusahatinggi dinyatakan dengan skor 17-20,9

5. Sikap kewirausahaan pengusaha sangat tinggi dinyatakan dengan skor $21-25$

\section{HASIL DAN PEMBAHASAN}

\section{Karakteristik Pengusah dan Profil Usaha Agroindustri Kedelai}

Pengusaha agroindustri tahu umur rata-rata 39 tahun, lama pendidikan 10 tahun (SMA), tanggungan keluarga 5 jiwa, pengalaman berusaha 10 tahun, dan jumlah tenaga kerja 4 jiwa. Sedangkan umur rata-rata pengusaha agroindustri tempe 37 tahun, lama pendidikan 9 tahun (SMP), tanggungan keluarga 4 jiwa, pengalaman berusaha 6 tahun, dan jumlah tenaga kerja 4 jiwa

Usaha agroindustri kedelai di Kecamatan Seberida Kabupaten Indragiri Hulu dimulai sejak tahun 1991, bentuk usaha rumah tangga yang bertujuan untuk mendapatkan tambahan pendapatan dan membuka lapang pekerjaan. Teknik pembuatan tahu diperoleh secara turun temurun dan juga dari bekerja dengan pengusaha lain. Usaha agroindustri tahu dan tempe yang dikelola oleh masingmasing pengusaha masih merupakan industri kecil, karena tenaga kerja yang digunakan masih relatif sedikit. Hal ini berdasarkan klasifikasi industri menurut Haryanto (1994), yang menyatakan bahwa industri kecil salah satu karakternya adalah penggunaan tenaga kerja antara 3-7 orang, dengan tidak memerlukan keahlian yang cukup tinggi. 


\section{B. Proses Pengolahan}

Teknologi yang digunakan dalam pengolahan kedelai untuk menghasilkan output berupa tahu dan tempe yaitu dengan menggunakan teknologi semi modern (mesin sederhana).

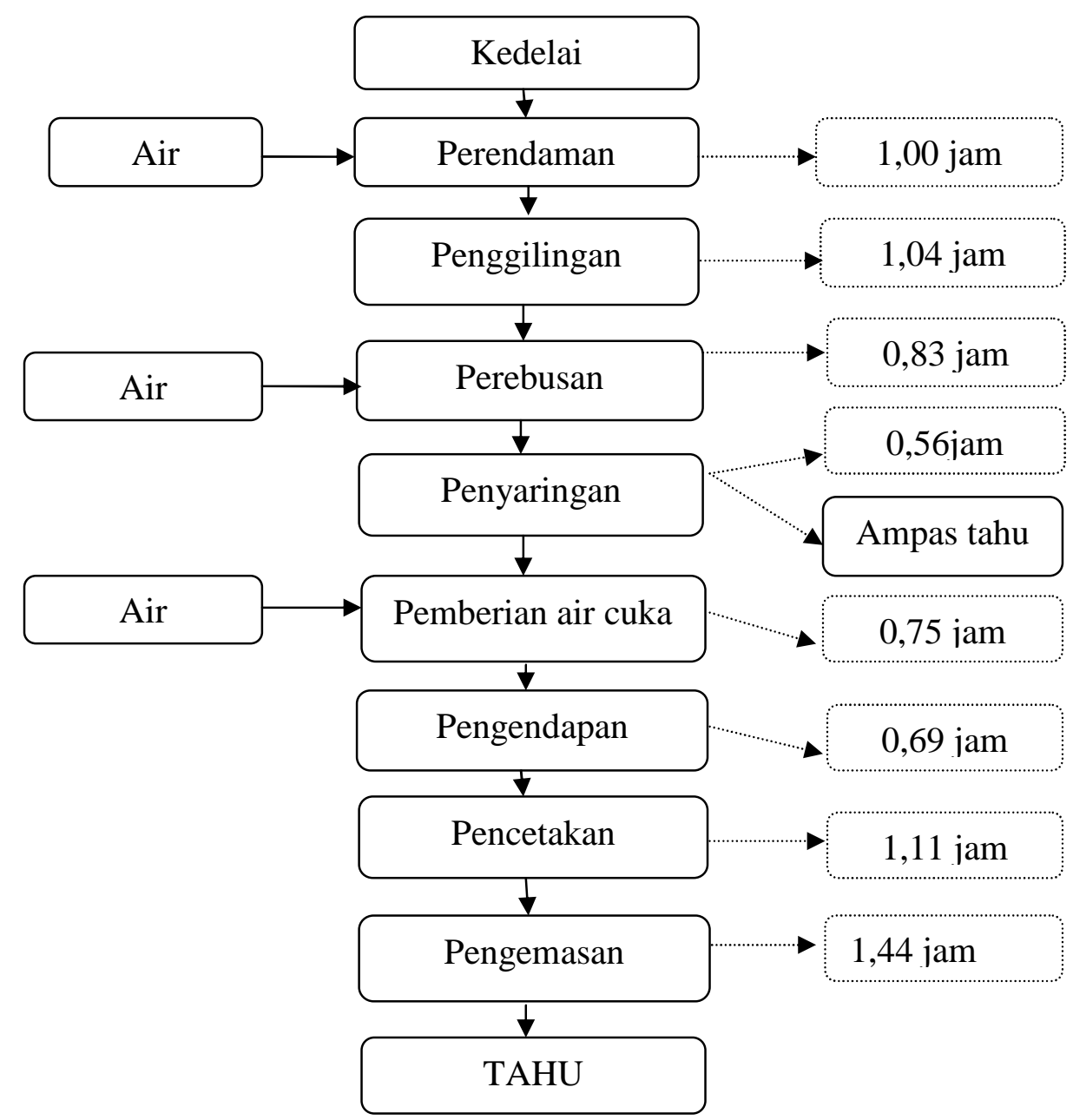

Gambar 1: Skema Pengolahan Kedelai Menjadi Tahu

Peralatan yang digunakan dalam proses agroindustri tempe adalah : Mesin penggiling digunakan untuk mengupas kulitkacang kedelai yang sudah direndam, Drum dengan ukuran besar yang digunakan untuk merebus biji kacang kedelai, Saringan dari plastik atom digunakan untuk memisahkan kacang kedelai dengan air, Cetakan tempe terbuat dari kayu yang sudah dibuat dengan bentuk persegi panjang yang digunakan untuk mencetak tempe, pisau stenlis digunakan untuk memotong tempe menjadi persegi panjang kecil-kecil, gayung digunakan untuk mengambil air, ember kecil, digunakan untuk memindahkan air, ember besar 
digunakan untuk menakar kedelai, plastik digunakan untuk pengisian kedelai, daun pisang digunakan untuk membungkus kedelai yang sudah diberi ragi.

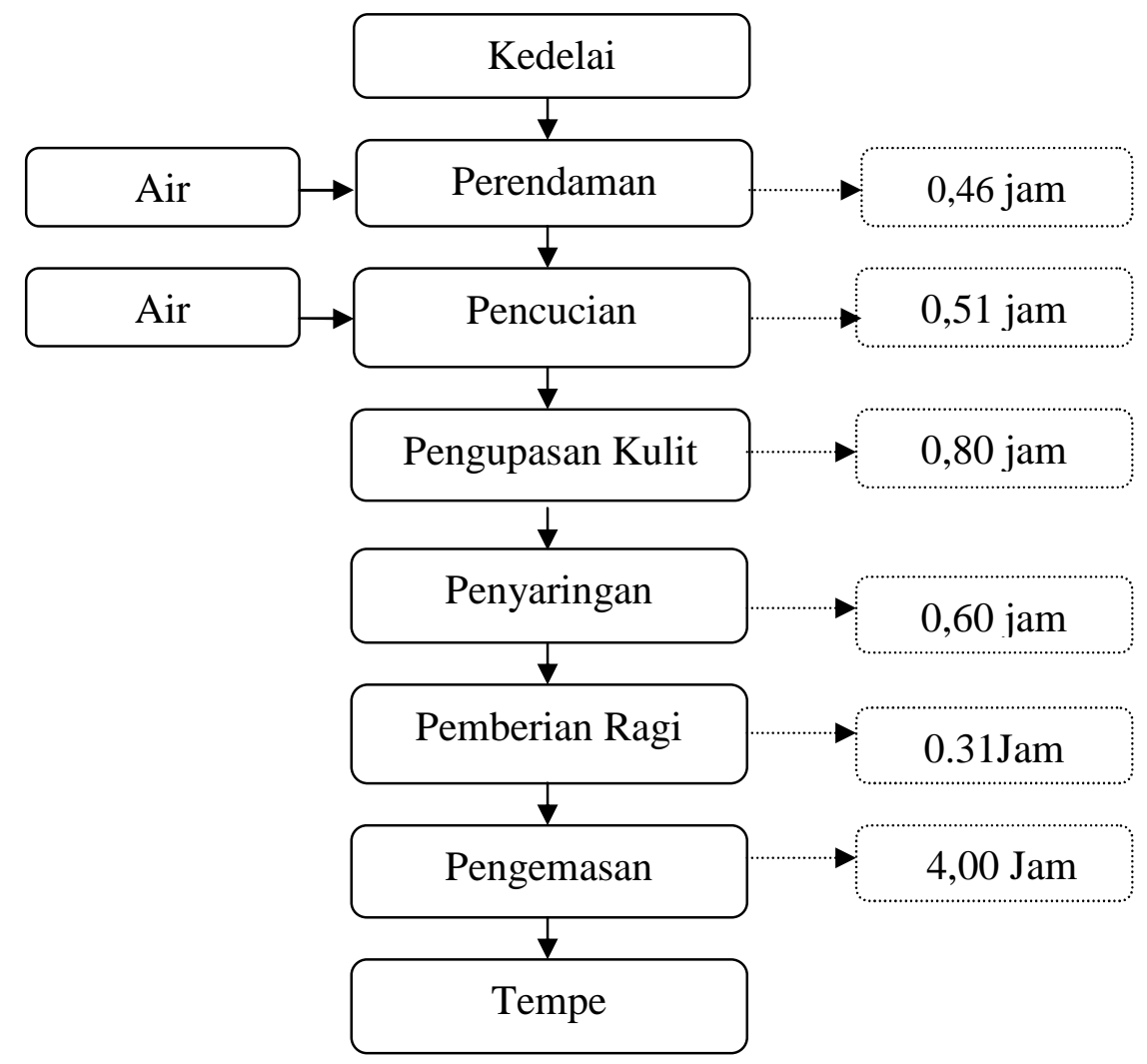

Gambar 2: Skema Pengolahan Kedelai Menjadi Tempe.

Adapun peralatan yang digunakan dalam proses agroindustri tempe di daerah penelitian adalah mesin penggiling digunakan untuk mengupas kulitkacang kedelai yang sudah direndam, drum dengan ukuran besar yang digunakan untuk merebus biji kacang kedelai, saringan dari plastik atom digunakan untuk memisahkan kacang kedelai dengan air, cetakan tempe terbuat dari kayu yang sudah dibuat dengan bentuk persegi panjang yang digunakan untuk mencetak tempe, pisau stenlis digunakan untuk memotong tempe menjadi persegi panjang kecil-kecil, gayung digunakan untuk mengambil air, ember kecil, digunakan untuk memindahkan air, ember besar digunakan untuk menakar kedelai, plastik digunakan untuk pengisian kedelai, daun pisang digunakan untuk membungkus kedelai yang sudah diberi ragi. 


\section{Analisis Usaha Agroindustri Kedelai}

Dalam mengelola usaha sangat penting dilakukan analisa usaha, karena dari analisa ini dapat diketahui kelayakan dari usaha. Hasil analisa agroindustri kedelai yang menghasilkan tahu dan tempe dapat dilihat pada Tabel 2.

Tabel 2. Jumlah Penggunaan Biaya Produksi, Produksi, Pendapatan, Usaha Agroindustri Kedelai Per Proses Produksi di Kecamatan Seberida Tahun 2016

\begin{tabular}{|c|c|c|c|c|c|c|c|}
\hline \multirow{3}{*}{$\begin{array}{l}\mathrm{N} \\
\mathrm{o}\end{array}$} & \multirow{3}{*}{ Uraian } & \multicolumn{6}{|c|}{ Usaha Agroindustri Kedelai } \\
\hline & & \multicolumn{3}{|c|}{ Tahu } & \multicolumn{3}{|c|}{ Tempe } \\
\hline & & $\begin{array}{l}\text { Jumlah } \\
\text { (unit) }\end{array}$ & $\begin{array}{c}\text { Harga } \\
\text { (Rp/unit) }\end{array}$ & Nilai (Rp) & $\begin{array}{l}\text { Jumlah } \\
\text { (unit) }\end{array}$ & $\begin{array}{c}\text { Harga } \\
\text { (Rp/unit) }\end{array}$ & Nilai (Rp) \\
\hline 1 & Bahan Baku (Kg) & 144 & 6.922 & 1.002 .222 & 157 & 6.914 & 1.089 .286 \\
\hline \multirow[t]{8}{*}{2.} & \multicolumn{7}{|l|}{ Bahan Penunjang } \\
\hline & Air cuka (liter) & 1 & 33.222 & 33.222 & & & \\
\hline & Solar (liter) & & 7.500 & 10.833 & 4 & 5833 & 33.333 \\
\hline & Kayu Bakar(Mobil) & 1 & 675.556 & 25.983 & 1 & 597143 & 22.967 \\
\hline & Plastik (bungkus) & 3 & 21.000 & 1.914 & & & 1.889 \\
\hline & Listrik & & & 5.926 & & & 5219.78 \\
\hline & Ragi (bungkus) & & & & 3 & 32571 & 20 \\
\hline & Daun Pisang & & & & 3 & 6143 & 19857 \\
\hline 3. & Biaya TK (Rp) & 1,76 & 52.778 & 94.455 & 2,80 & 47.857 & 136.640 \\
\hline 4. & Penyusutan Alat (Rp) & & & 680,64 & & & 299,54 \\
\hline 5. & Total Biaya Produksi & & & 1.127 .561 & & & 1.280 .508 \\
\hline 6. & Produksi (Kg) & 260 & 6.833 & 1.776 .944 & 411 & 4.429 & 1.846 .429 \\
\hline 7. & \multicolumn{7}{|l|}{ Pendapatan } \\
\hline & 1. Kotor (Rp) & & & 1.776 .944 & & & 1.846 .429 \\
\hline & 2. Bersih (Rp) & & & 649.384 & & & 461.724 \\
\hline 8. & RCR & \multirow{2}{*}{\multicolumn{3}{|c|}{$\begin{array}{c}1,58 \\
5924\end{array}$}} & \multicolumn{3}{|c|}{1,43} \\
\hline 9. & ROI (\%) & & & 59,24 & \multicolumn{3}{|c|}{43,68} \\
\hline
\end{tabular}

Biaya yang di keluarkan terbesar baik pada agroindustri tahu maupun tempe adalah biaya bahan baku (kacang kedelai) yaitu untuk tahu sebesar Rp 1.002.222 (88,88\%) dan tempe Rp 1.089.286 (85,07). Bahan baku kacang kedelai yang digunakan adalah kedelai impor karena kualitas lebih baik, dan jumlah yang digunakan lebih banyak dibandingkan bahan lainnya, sehingga memerlukan biaya yang lebih besar.Kebutuhan bahan baku kedelai untuk tahu rata-rata $144 \mathrm{Kg}$ dan menghasilkan tahu sebanyak $260 \mathrm{~kg}$ per proses, sedangkan untuk tempe sebanyak $157 \mathrm{Kg}$ dengan produksi $411 \mathrm{~kg}$ tempe.

Pendapatan Bersihyang diperoleh per proses produksi untuk tahu adalah Rp 649,384, dan tempe sebesar Rp 565,921. Nilai Return Cost Ratio (RCR) yang diperoleh agroindustri tahu adalah 1,58 dan tempe 1,43. Ini bermakna bahwa setiap Rp 1,00 biaya yang dikeluarkan dalam agroindustri tahu, akan memperoleh pendapatan kotor sebesar Rp 1,58(Tahu) dan Rp 1,43 (Tempe) atau pendapatan bersih sebesar Rp 0,58 (Tahu) dan Rp 0,43 (Tempe). Hal ini berarti agroindustri 
tahu dan tempe ini layak atau menguntungkan untuk diusahakan dan dikembangkan karena dapat memberikan imbalan jasa ekonomi berupa keuntungan.Nilai RCR ini lebih tinggi dibandingkan dengan hasil penelitian yang dilakukan oleh Chandra (2013) di Desa Sungai Tohor Kecamatan Tebing Tinggi Timur, dimana RCR sebesar 1,39. Dengan demikian, usaha yang dikembangkan di Kecamatan Siberida lebih menguntungkan.

\section{Analisis Nilai Tambah}

Nilai tambah dapat diartikan sebagai imbalan jasa dari alokasi tenaga kerja dan keuntungan pengrajin. Besar kecilnya nilai tambah produk agroindustri sangat tergantung pada teknologi yang digunakan dalam proses pengolahan dan perlakuan lainnya terhadap produk tersebut. Nilai tambah dari usaha agroindustri tahu dan tempe dapat dilihat pada Tabel 3.

Nilai tambah agroindustri pengolahan kedelai menghasilkan output sebanyak 312,22 Kg (tahu) dan 410,71 Kg(tempe) /proses produksi, dengan input yang digunakan adalah 144,44 Kg (tahu) 157,14 (tempe)/proses produksi. Tenaga kerja (HOK) yang digunakan pada agroindustri tahu 1,76HOK 2,80 HOK tempe.

Faktor konversi diperoleh dari hasil output dibagi dengan input adalah 2,16(tahu) 2,61 (tempe) artinya banyaknya output yang dapat dihasilkan dari satusatuan input. Koefisien tenaga kerja yang diperoleh dari hasil tenaga kerja dibagi dengan input yaitu 0,01 dan 0,02 HOK. Harga output Rp 6,833Kg untuk tahu Rp 4.428,57 untuk tempe. dan upah tenaga kerja sebanyak Rp 52,778(tahu) 47.857,14 (tempe) HOK.

Harga bahan baku kg kedelai $\mathrm{Rp} 6,922 / \mathrm{Kg} \mathrm{Rp} 6.914,29 / \mathrm{kg}$, sumbangan input lain diperoleh dari biaya pemakaian input lain per/kg produk yaitu $\mathrm{Rp}$ 6,488Rp 2995,37/Kg. Nilai output tahu yang dihasilkan dari faktor konversi dikali dengan harga output sebesar Rp 14,771/Kg tahu Rp 11.574,68. Nilai tambah ini diperoleh dari pengurangan nilai output produksi tahu dengan biaya bahan baku dan bahan penunjang lainnya. Nilai tambah yang diperoleh dari pengolahan kedelai per proses produksi menjadi tahu adalah sebesar $\mathrm{Rp} 14,771 / \mathrm{Kg}$ tahu $\mathrm{Rp}$ 11.574,68 tempe bahan baku, artinya dalam Rp 6,922/Kg (tahu) Rp 6.914,29/kg (tempe) harga bahan baku menghasilkan nilai tambah $\mathrm{Rp} 14,771 / \mathrm{Kg}$ tahu $\mathrm{Rp}$ 11.574,68 tempe $/ \mathrm{kg}$ bahan baku. Rasio nilai tambah tahu adalah sebesar 9,21\% dan $14,39 \%$ artinya dari nilai output tahu dan tempe merupakan nilai tambah 
yang diperoleh dari agroindustri kedelai. Pendapatan tenaga kerja diperoleh dari koefisien tenaga kerja dikali dengan upah tenaga kerja adalah sebesar Rp 643,55 tahu 853,23 tempe /Kg. Pangsa tenaga kerja yang diperoleh adalah 47,33\% dan $51,24 \%$. Pangsa tenaga kerja adalalah menunjukkan presentase tenaga kerja dari nilai tambah. Keuntung nilai tambah pada tahu yaitu dengan keuntungan Rp 716,27 tahu Rp 811,79 tempe, dan tingkat keuntungan yang diperoleh sebesar $52,67 \%$ dan $48,76 \%$.

Tabel 3. Nilai Tambah Metode Hayami Usaha Agroindustri Kedelai Per Proses Produksi Di Kecematan Seberida Tahun 2016

\begin{tabular}{|l|r|r|}
\hline \multicolumn{2}{|c|}{ Nilai Tambah } & \multicolumn{2}{c|}{ Tahu } & Nempe \\
\hline I. Output, Input dan Harga & \multicolumn{2}{|c|}{} \\
\hline 1. Output (Kg/proses) & 312,22 & 410,71 \\
\hline 2. Input (Kg/proses) & 144,44 & 157,14 \\
\hline 3. Tenaga kerja (HOK) & 1,76 & 2,80 \\
\hline 4. Faktor konversi & 2,16 & 2,61 \\
\hline 5. Koefisien Tenaga kerja (HOK/Kg) & 0,01 & 0,02 \\
\hline 6. Harga output (Rp) & 6.833 & 4.429 \\
\hline 7. Upah tenaga kerja (Rp/HOK) & 52.778 & 47.857 \\
\hline II. Penerimaan dan Keuntungan & & 6.914 \\
\hline 8. Harga bahan baku (Rp/kg) & 6.922 & 2.995 \\
\hline 9. Sumbangan input lain (Rp/kg) & 6.488 & 11.575 \\
\hline 10. Nilai output (Rp/kg) & 14.771 & 1.665 \\
\hline 11.a. Nilai tambah (Rp/kg) & 1.360 & 14,39 \\
\hline b. Rasio nilai tambah (\%) & 9,21 & 853,23 \\
\hline 12. a. Pendapatan Tenaga Kerja (Rp/kg) & 643,55 & 51,24 \\
\hline b. Pangsa tenaga kerja (\%) & 47,33 & 811,79 \\
\hline 13. a. Keuntungan (Rp/proses) & 716,27 & 48,76 \\
\hline b. Tingkat keuntungan (\%) & 52,67 & \\
\hline
\end{tabular}

\section{Analisi Tingkat Pengembalian Investasi (ROI)}

ROI merupakan alat pengukur kemampuan perusahaan dalam menghasilkan keuntungan dengan seluruh aktiva yang tersedia di dalam perusahaan dengan melihat sampai seberapa besar tingkat laba yang dihasilkan atas sejumlah investasi yang telah ditanamkan. Untuk lebih jelasnya dapat dilihat pada Tabel 4. 
Tabel 4. Tingkat Pengembalian Usaha Agroindustri Kedelaidi Kecamatan SeberidaTahun 2016

\begin{tabular}{|l|l|r|r|}
\hline No & \multicolumn{1}{|c|}{ Uraian } & \multicolumn{1}{c|}{ Tahu } & \multicolumn{1}{c|}{ Tempe } \\
\hline 1 & Pendapatan Kotor & 1.776 .944 & 1.846 .429 \\
\hline 2 & TVC & 1.121 .072 & 1.277 .512 \\
\hline 3 & ROI $(\%)$ & 59,24 & 43,68 \\
\hline
\end{tabular}

Pada Tabel 4 menunjukkan pendapatan kotor agroindustri tahu $\mathrm{Rp}$ 1.776.944, TVC Rp 1.121.072 dan ROI 59,24 \%sedangkan untuk agroindustri tempe pendapatan kotor sebesar Rp 1.846.429, TVC Rp 1.277.512 dan ROI 43,68 $\%$ artinya 100,- biaya yang produksi yang di keluarkan dalam usaha agroindustri tempe di Kecamatan Seberida akan memberikan keuntungan sebesar 59,24\% unutk tahu dan $43,68 \%$ untuk tempe.

\section{Sikap Kewirausahan Pengusaha}

Sikap kewirausahaan adalah kecenderungan berperilaku yangseseorang dalam menangani usaha atau kegiatan yang mengarah padamenciptakan dan menerapkan cara kerja dalam rangka memberikanpelayanan yang lebih baik serta memperoleh keuntungan.Dalam hal ini yang dinilai adalah sikap kewirausahaan yangdimiliki pengusaha (percaya diri, memiliki inisiatif, memiliki motif berprestasi, memiliki jiwa kepemimpinan dan brani mengambil resiko dengan penuh perhitungan), dimana pengusaha merupakan pemilik usaha Agroindustri kedelai. Untuk lebih jelasnya dapat dilihat pada Tabel 5.

Tabel 5. Persentase Sikap Kewirausahaan Pengusaha Agroindustri Kedelai di Kecamatan Seberida Tahun 2016

\begin{tabular}{|l|c|c|c|c|}
\hline \multirow{2}{*}{ Kriteria } & \multicolumn{2}{|c|}{ Tahu } & \multicolumn{2}{c|}{ Tempe } \\
\cline { 2 - 5 } & $\begin{array}{c}\text { Jumlah pengusaha } \\
\text { (Jiwa) }\end{array}$ & $\begin{array}{c}\text { Persentase } \\
\%\end{array}$ & $\begin{array}{c}\text { Jumlah pengusaha } \\
\text { (Jiwa) }\end{array}$ & Persentase \% \\
\hline Sangat Tinggi & 4 & 44,44 & 2 & 28,57 \\
\hline Tinggi & 3 & 33,33 & 5 & 71,43 \\
\hline Sedang & 2 & 22,22 & 0 & 0,00 \\
\hline Rendah & 0 & 0,00 & 0 & 0,00 \\
\hline Sangat Rendah & 0 & 0,00 & 0 & 0,00 \\
\hline Jumlah & 9 & 100,00 & 7 & 100,00 \\
\hline
\end{tabular}

Sikap kewirausahaan pengusaha tahu di Kecamatan Seberida dengan kriteria sangat tinggi jumlah pengusaha 4 jiwa dengan persentase 44,44\%, kriteria tinggi 3 jiwa $(33,33 \%)$ dan yang paling sedikit ada kriteria sedang yaitu 2 jiwa 
dengan nilai persentase (22,22 \%).Sedangkan pada sikap kewiraushaan pengusaha tempe di Kecamatan Seberida kriteria tinggi memiliki jumlah paling banyak yaitu 5 jiwa dengan persentase $(71,43 \%)$ dan kriteria sangat tinggi hanya 2 jiwa (28,57\%). Jika dilihat Pada kedua pengusaha tahu dan tempe dari lima variabel(Percaya Diri, Memiliki Insiatif, Memilik Motif Berprestasi,Memiliki Jiwa Kemimpinandan Brani Mengambil Resiko Dengan Penuh Perhitungan)yang ada sudah dikatakan kategori memiliki sikap kewirausahaan yang tinggi, pengukuran ini dapat dilihat dengan jumlah dari semua variabel. Untuk lebih jelasnya dapat dilihat pada Tabel 6 .

Tabel 6. Skor Sikap Kewirausahaan Pengusaha Agroindustri Kedelai di Kecamatan Seberida Tahun 2016

\begin{tabular}{|l|c|c|}
\hline \multicolumn{2}{|c|}{ variabel } & \multicolumn{2}{c|}{ Skor Sikap Kewirausahaan } \\
\cline { 2 - 3 } & Tahu & Tempe \\
\hline Percaya Diri & 3,9 & 4,1 \\
\hline Memiliki Insiatif & 3,9 & 3,9 \\
\hline Memilik Motif Berprestasi & 3,8 & 3,9 \\
\hline Memiliki Jiwa Kemimpinan & 3,9 & 4,0 \\
\hline $\begin{array}{l}\text { Berani Mengambil Resiko Dengan } \\
\text { Penuh Perhitungan }\end{array}$ & 3,9 & 3,6 \\
\hline Jumlah & 19,3 & 19,4 \\
\hline
\end{tabular}

Pada Tabel 6 menjelaskan pengukuran pada setiap variabel yang dimiliki oleh pengusaha agroindustri kedelai di Kecamatan Seberida, jumlah dari skor sikapkewirausahaan pengusaha agroindustri tahu menunjukkan 19,3 yang dimana ini berarti memiliki kriteria tinggi, sedangkan untuk skor sikap kewirausahaan pengusaha agroindustri tempe 19,4 dengankriteria tinggi.

\section{Percaya Diri}

Percaya diri adalah kondisi mental atau psikologis diri seseorang yang memberi keyakinan kuat pada drinya untuk berbuat atau melakukan sesuatu tindakan.

Pada lampiran 8 variabel percaya diri pada pengusaha agroindustri tahu yaitu berjumlah 35 dengan Rata-rata 3,9 ini berarti untuk sikap kewirausahaan dengan variabel percaya diri berada pada kriteria sedang. pada sikap kewirusahaan agroindustri tempe dengan variabel percaya diri yaitu berjumlah 29 lebih kecil 
dari variabel agroindustri tahu tetapi masih pada kriteria skor 4,1 yaitu berarti tinggi.

\section{Memilii Inisiatif}

Memiliki Inisiatif adalah kemampuan untuk memutuskan dan melakukan sesuatu yang benar tanpa harus di beritahu. Pada pengusaha agroindustri tahu jumlah dari variabel memiliki inisiatif yaitu 35 dengan rata-rata 3,9 dan agroindustri tempe yaitu 27 rata-rata 3,9 jumlah pada variebel sikap pengusaha tempe lebih kecil dari variabel pada pengusaha agroindustri tahu. Dapat dilihat pada Lampiran 8.

\section{Memiliki Motif Berprestasi}

Motif berprestasi sebagai dorongan yang berhubungan dengan prestasi yaitu menguasai, mengatur lingkungan social, atau fisik, mengatasi rintangan atau memilihara kualitas kerja yang tinggi, bersaing melebihi prestasi yang lampau dan mempengaruhi orang lain. pada lampiran 8 untuk sikap kewirausahaan pengusaha tahu dengan jumlah 34 rata-rata 3,8yaitu sedang dan untuk sikap kewirausahaan pengusaha agroindustri tempe dengan variabel motif berprestasi yaitu 27 dengan rata-rata 3,9yaitu kriteria sedang.

\section{Memiliki Jiwa Kepemimpinan}

Jiwa kepemimpinan adalah proses mempengaruhi atau memberi contoh oleh pemimpin kepada bawahanya dalam upaya memcapai tujuan. Untuk jumlah variabel memiliki jiwa kepemimpinan pada pengusaha agroindustri tahu yaitu 35 dengan rata-rata 3.9dengan kriteria sedang dan pada pengusaha agroindustri tempe 28 dengan rata-rata 4,0 yang berarti kriteria tinggi.

\section{Barani Mengambil Resiko Dengan Penuh Perhitungan}

Berani mengambil risiko adalah kekuatan dalam diri untuk mampu menentukan, menetapkan dan merumuskan apa yang akan di ambil dan diterima. Pada lampiran8 untuk sikap barani mengambil resiko dengan penuh perhitungan pada pengusaha agroindustri tahu yaitu dengan jumlah 35 rata-rata 3,9 dan pada pengusaha agroindustri tempe 25 rata-rata 3,6 dengan kriteria sedang untuk pengusaha tahu dan tempe. 


\section{Kesimpulan}

\section{KESIMPULAN DAN SARAN}

1. Usaha agroindustri tahu dan tempe merupakan usaha kecil per seorangan, teknologi semi mekanis, belum memiliki merek dagang dan izin usaha secara resmi. Bahan baku yang digunakan dalam satu kali proses untuk agroindustri tahu adalah kedelai sebanyak $144 \mathrm{~kg}$, dengan bahan penunjang berupa air cuka, solar, kayu bakar, dan plastik. Biaya terbesar adalah untuk bahan baku yaitu Rp. 1002.222 (88,88\%), pendapatan bersih Rp 649.384, RCR sebesar 1,59.Nilai tambah yang diperoleh sebesar Rp 1.360 dan investasi (ROI) 59,24 $\%$.Sedangkan untuk agroindustri tempepenggunaan bahan baku (kedelai)157 $\mathrm{kg}$, biaya produksi agroindustri tempe sebesarRp 1.089.286, biaya terbesar adalah bahan baku yaitu Rp. 1.089.286 (85,06\%), pendapatan bersih565.921, RCR sebesar 1,43. Nilai tambah yang diperoleh sebesar Rp 1.665/kg, investasi (ROI) 43,68\% . artinya 100,- biaya yang produksi yang di keluarkan dalam usaha agroindustri kedelai diKecamatan Seberida akan memberikan keuntungan sebesar 59,24 untuk tahu dan 43,68\% untuk tempe.

2. Sikap kewirausahaan pengusahaagroindustri kedelaisecara keseluruhan meliputi percaya diri, memiliki inisiatif, memiliki motif berprestasi, memiliki jiwa kepemimpinan dan berani mengambil resiko dengan penuh perhitungan adalah sangat tinggi untuk sikap kewirausahaan agroindustri tahu dan tinggi untuk sikap kewirausahaan agroindustri tempe.

\section{Saran}

Hingga saat ini pengrajin menggunakan kedelai impor yang harganya lebih mahal, oleh karena itu, hasil penelitiaan ini diharapkan dapat. menjadi bahan pertimbangan bagi pengusaha dalam pengambilan keputusan, dan bagi pemerintah daerah sebagai bahan pertimbangan dalam menyusun kebijakan yang lebih baik di masa yang akan datang, terutama dalam industri rumah tangga.

\section{DAFTAR PUSTAKA}

Badan Pusat Statistik Provinsi Riau. (2014). Riau Dalam Angka. Pekanbaru .2014. Nilai PDB menurut Lapangan Usaha Berdasarkan Harga Konstan 2011-2013. Pekanbaru. Riau. 
Badan Pusat Statistik Kabupaten Indragiri Hulu. (2015). Kecamatan Seberida Dalam Angka 2015. Rengat

Badan Pusat Statistik Kabupaten Indragiri Hulu (2015). Statistik Kecamatan Seberida 2015. Rengat

Budiman. A., Jum'arti. Y., Ermi. T. 2012. Analisis Efesiensi dan nilai Tambah Agroindustri Tahu di Kota Pekanbaru. Jurnal Agribisnis.

Chandra. 2013. Analisis Agroindustri Sagu Basah Di Desa Sungai Tohor Kecamatan Tebing Tinggi Timur Kabupaten Kepulauan Meranti. Skripsi Agribisnis, Fakultas Pertanian. Universitas Islam Riau. (Tidak Dipublikasikan).

Cahyadi. 2007. Kedelai Khasiat dan Teknologi. Bumi Aksara. Jakarta.

Dayaksini, 2004. Psikologi Lintas Budaya.Press, Malang

Gibson, James L. Et Al. 1989.Organisasi Perilaku Struktur, Proses Editor Oleh Agus Dahrma Sh M,Ed, Erlangga, Jakarta

Hayami, Y. Et Al. 1987. Agricultural Marketing And Processing In Upland Java. A Perspective From A Sunda Village. Cgprt Centre, Bogor.

Haryono, 1984. Metode Statistika. Surabaya. ITS Surabaya

Hernanto. 1996. Ilmu Usahatani. Penebar Swadaya, Jakarta.

Irwan. 2006. Budidaya Tanaman Kedelai. Unpad Press. Jatinagor, Bandung

Mubyanto. 1998. Pengantar Ekonomi Pertanian. Pustaka LP3ES, Jakarta.

Mulyadi 2001. Balanced Scorecard Alat Manajemen Kontemporer Untuk Pelipat Gandaan Kinerja Keuangan Perusahaan Salemba Empat, Jakarta

Rahardi.1999. Agribisnis Tanaman Buah. Penebar Swadaya, Jakarta.

Rawuh, S. 2013. Cara Menghitung Roi. Http://Andheek.Wordpress. Com. /2013 /05/15/Cara - Menghiutng-Roi Retrun-On-Investment. (Diakses Tanggal 16 November 2015).

Saiman, L. 2009. Kewirausahaan, Teori, Praktek, dan Kasus: Salemba Empat, Jakarta

Setiawati D, 2013. Kontribusi Pendapatan Agroindustri Dawet Ireng Terhadap Pendapatan Keluarga Pengerajin Di Kecamatan Butuh Di Kabupaten Purwerejo. Jurnal Ekonomi, 2 (2) : 13-22

Sudirman. 1984. Media Pembelajaran, Pengertian, Pengembangan, Penetapan. Rajawali, Jakarta. 
Suhendar, A. 2002. Visual Modelling Menggunakan UML dan Rational Rose. Informatika Bandung.

Sukyadi. 2007. Kewirausahaan:Untuk Pemelajar Bahasa dan Seni.Bandung: Basen Press.

Sukirno, S. 1997. Ekonomi Pembangunan, Proses Masalah dan Dasar Kebijaksanaan. Penerbit LPEE-UI dan Bina Grafika, Jakarta.

Sumodiningrat G. 2001.Menuju Swasembada Pangan Revolusi Hijau. Jakarta: Rbi.

Sugiono. 2008. Metode Penelitian Kuantitatif, Kualitatif Dan R \& D. Alfabeta, Bandung.

Simamora, 2002. Akuntasi Manajemen Edisi Ke-2. Yogyakarta. UPP YKPN, Yogyakarta

Soekartawi. 1999. Manfaat Proses Pengolahan Komoditi Pertanian. PT. Raja Grafindo Persada. Jakarta.

1995. Analisis Usahatani. Universitas Indonesia, Jakarta.

_ 2001. Pengantar Agroindutri. PT. Raja Grafindo Persada. Jakarta.

2002. Prinsip Dasar Ekonomi Pertanian Teori dan Aplikasinya. PT Raja Grafindo Persada, Jakarta.

Soemanto. 2008. Pendidikan Kewirausahaan. Bumi Aksara,Jakartan

Suryana. 2013. Kewirausahaan. Jakarta. Salemba Empat.

Tarigan, R, 2004. Ekonomi Regional. Bumi Aksara, Jakarta.

Tastra. 2007. Teknologi Pasca Panen Primer Kedelai. Dalam Edisi Sumarno Et Al. Kedelai Teknik Produksi dan Pengembangan. Puslitbang Pangan, Bogor

Taufiq dan Novo. 2004. Kedelai, Kacang Hijau dan Kacang Panjang. Absolut Press. Yogyakarta

Umar. 1999. Metodologi Penelitian: Aplikasi Dalam Pemasaran,PT. Gramedia Pustaka Utama, Jakarta.

Umar, 2003. Meteode Riset Bisnis. Gramedia Pustaka Utama,Jakarta

Walgito, Bimo. 2002. Psikologi Sosial (Suatu Pengantar). AndiOffset, Yogyakarta

Wardhani. R. M. 2010. Peranan Agroindustri Dalam Meningkatkan Nilai Tambah Komoditi Pisang, Nangka dan Garut. Jurnal Agritek, 11 (1). 
Yasin. A.Z.Fdan Muchtar Ahmad.1996. Usahatani Kecil, Kelembagaan Dan Agribisnis, Unri Press, Pekanbaru.

Yuto, dan Nugent dalam A Marhasan. (2005). Efesiensi Usaha Tani Tembakau Berdasarkan Perbedaan Luas Lahan Garapan, Tesis. Universitas Gajah Mada, Yogjakarta

Zaki. 1997. Intermediate Accounting. BPFE, Yogyakarta. 